\title{
MEĐUKNJIŽNIČNA POSUDBA \\ U ERI DIGITALNE DOSTUPNOSTI ZNANSTVENIH \\ INFORMACIJA
}

\author{
AVAILABILITY OF SCIENTIFIC INFORMATION \\ IN THE DIGITAL AGE AND ITS INFLUENCE ON \\ INTERLIBRARY LOAN AND DOCUMENT DELIVERY
}

\begin{abstract}
Sofija Konjević
Centar za znanstvene informacije

Institut Ruđer Bošković

sofija@irb.hr
\end{abstract}

UDK / UDC 025.6: [004:001.102]
Pregledni rad / Review paper
Primljeno / Received: 12. 3. 2020.
Prihvaćeno / Accepted: 24. 8. 2020.

\section{Sažetak ${ }^{1}$ :}

Cilj. Rad daje prikaz utjecaja tehnoloških promjena, osobito mrežne dostupnosti e-izvora znanstvenih informacija na službu međuknjižnične posudbe rabeći kao primjer podatke o međuknjižničnoj posudbi (MKP) Centra za znanstvene informacije, uz osvrt na trendove u Europi i svijetu.

Pristup. Rad donosi kratak povijesni pregled razvoja službe međuknjižnične posudbe, prikaz tehnoloških promjena, s naglaskom na dostupnost građe u digitalnom formatu bilo pretplatom ili u otvorenom pristupu i promjene koje donosi, istovremeno olakšavajući proces međuknjižnične posudbe, ali i donoseći određena ograničenja. Analizirani su podaci o broju zahtjeva u Centru za znanstvene informacije Instituta Ruđer Bošković, a dan je i pregled današnje situacije u svijetu.

\footnotetext{
1 Rad je na hrvatskom jeziku prezentiran na stručnom skupu "Izgradnja, upravljanje i evaluacija zbirki", 12. 4. 2019., Zagreb, Hrvatska, a na engleskom jeziku na konferenciji River of no Return: Sail or Sink: 18th Biennial Conference of the European Association of Aquatic Sciences Libraries and Information Centres (EURASLIC), 6-9.5.2019., Zagreb, Hrvatska. Prošireni sažetak na engleskom jeziku objavljen je u zborniku konferencije EURASLIC.
}

Vjesnik bibliotekara Hrvatske 63, 1-2(2020), 185-208 ISSN 0507-1925 
Rezultati. Analiza je pokazala da velik broj zahtjeva za međuknjižničnom posudbom CZI bilježi sve do 2013. godine, nakon čega je registriran konstantan pad u broju zahtjeva, što je u skladu i s nekim primjerima u svijetu koji su prikazani u radu.

Originalnost. Tema je obrađivana u prošlosti, no malo je novijih radova u Hrvatskoj koji obrađuju utjecaj tehnoloških promjena i digitalne građe na samu službu međuknjižnične posudbe, dajući pri tom opsežan pregled trenutnog stanja u svijetu. U svjetlu navedenih promjena analizirani su i prikazani statistički podaci međuknjižnične posudbe Centra za znanstvene informacije.

Ključne riječi: međuknjižnična posudba, MKP, dostava dokumenata, opskrba dokumenata, e-izvori, znanstvene informacije

\begin{abstract}
Purpose. The purpose of this paper is to give insight into the current state of international interlibrary loan (ILL) in the light of technological changes and availability of e-resources of scientific information and their influence to the service, using Centre for Scientific Information (CSI) interlibrary loan statistical data as an example.
\end{abstract}

Approach. The paper gives brief introduction to historical development of interlibrary loan, technological changes and proliferation of scientific literature available in digital format either by subscription or in open access and its influence on ILL service. The changes facilitated the service but also brought some limitations. An overview on the current state of the ILL service in Europe and worldwide is given along with CSI statistical data that are analyzed and presented.

Findings. The analyzes showed very high number of ILL requests at CSI until 2013. After that continuous decrease in ILL requests is noticed, which coincide with some examples in the world that are presented in this paper.

Originality/Value. There are articles on the subject, but not too many recent ones in Croatia tackling the technological changes and digital publications and its influence on the service. The article provide an in-depth overview of the current state of international interlibrary loan together with analysis of the ILL service at the CSI.

Keywords: interlibrary loan, ILL, document delivery, document supply, resourse sharing, e-resources, scientific information

\title{
1. Uvod
}

Međuknjižnična posudba usluga je kojom knjižnica knjižničnu građu koju ne posjeduje u svom fondu nabavlja od drugih knjižnica, dok se drugim knjižnicama omogućuje posudba građe iz fonda knjižnice. Način poslovanja međuknjižnič- 
ne posudbe mijenjao se $\mathrm{u}$ skladu s tehnološkim promjenama $\mathrm{u}$ društvu, a osobit utjecaj imala je automatizacija poslovanja knjižnica, pojava interneta i mrežnih kataloga, kao i pojava građe u digitalnom formatu.

Zbog porasta broja e-publikacija i sve veće dostupnosti cjelovitog teksta radova neka predviđanja ${ }^{23}$ ukazivala su na smanjivanje značaja ili čak nestanak usluge međuknjižnične posudbe. U isto vrijeme zahvaljujući pojavi mrežnih kataloga i mrežno dostupnih informacija o knjižničnoj građi korisnici lakše lociraju knjižnicu koja posjeduje građu, što olakšava slanje zahtjeva te se i porast broja zahtjeva činio izgledan. Tu kontradiktornost potvrđuju i neka od ranih istraživanja. Neka istraživanja bilježe pad u broju zahtjeva ${ }^{456}$, a u isto vrijeme neka druga bilježe porast broja zahtjeva ${ }^{78}$. Tako npr. knjižnice društva ARL (Association of Research Libraries) u periodu između 1996. - 2002. godine bilježe porast u broju zahtjeva, za razliku od British Library Document Supply Centra (BLDSC) gdje prema podacima za 1998./1999., 2001./2002. dolazi do smanjenja zahtjeva. No osim porasta dostupnih e-izvora, razlog smanjenju broja zahtjeva u toj ranoj fazi pojave e-izvora mogla bi biti i pojava drugih servisa prema kojima su knjižnice preusmjeravale svoje zahtjeve. ${ }^{9}$

Kako su tehnološke promjene utjecale na uslugu međuknjižnične posudbe i je li zbog mrežne dostupnosti e-izvora u skladu s predviđanjima porastao ili se smanjio značaj usluge MKP-a, bit će prikazano u radu uz poseban osvrt na međuknjižničnu posudbu Centra za znanstvene informacije.

2 Jackson, M.E. Will electronic journals eliminate the need for ILL? // Interlending \& Document Supply 32, 3(2004), str. 192. DOI: https://doi.org/10.1108/02641610410699768.

3 Echeverria, M.; P. Barredo. Online journals: their impact on document delivery. // Interlending \& Document Supply 33, 3(2005), 145-149. DOI: https://doi.org/10.1108/02641610510618036.

4 Isto.

5 Jackson, M.E. Nav. dj., str. 192

6 Wiley, L.; T. E. Chrzastowski.The impact of electronic journals on interlibrary lending: a longitudinal study of statewide interlibrary loan article sharing in Illinois. // Library Collections, Acquisitions, and Technical Services 29, 4(2005), 364-368. DOI: https://doi.org/10.1016/j. lcats.2006.03.015.

7 Yue, P.W.; M. L. Syring. Usage of electronic journals and their effect on interlibrary loan: a case study at the University of Nevada, Reno. // Library Collections, Acquisitions, and Technical Services 28, 4(2004), 420-432. DOI: https://doi.org/10.1016/j.lcats.2004.08.002.

8 Jackson, M.E. Nav. dj., str. 193

9 Isto, str. 192. 


\section{Kratka povijest međuknjižnične posudbe}

Prve naznake o suradnji između knjižnica ukazuju da su još u 8. stoljeću samostani Sankt Kilian i Fulda razmjenjivali knjige. ${ }^{10}$ Posudba knjiga i rukopisa između samostana bila je uobičajena u srednjem vijeku iako je bilo i samostana koji su striktno zabranjivali takvu posudbu. Također je tijekom srednjeg vijeka zabilježena razmjena knjiga u islamskom svijetu između Cordobe i Bagdada ${ }^{11}$.

U 13. stoljeću javljaju se katalozi samostanskih knjižnica gdje je uz opis građe navedeno i koja knjižnica posjeduje građu. ${ }^{12}$ Tijekom renesanse dolazi do razvoja knjižnica, a zabilježeni su i neformalni dogovori između knjižnica različitih država o međuknjižničnoj posudbi. Nicolas Claude Fabri de Peiresc, francuski astronom i humanist, pokušao je dogovoriti suradnju i međuknjižničnu posudbu između Kraljevske knjižnice u Parizu ${ }^{13}$, Vatikanske knjižnice i Barberini knjižnice, no, nažalost, nije uspio u naumu. ${ }^{14}$ Knjižnice Lund, Abo i Greifswald u 18. stoljeću potpisuju sporazum o razmjeni građe, dok knjižnice sveučilišta Wolfenbuttel i Göttingen koordiniraju nabavu građe..$^{15}$ Unatoč tome što je postojala posudba građe između knjižnica, još krajem 19. stoljeća postoje knjižnice gdje je zakonom bila zabranjena posudba građe korisnicima izvan knjižničnog prostora. ${ }^{16} \mathrm{U}$ SAD-u kao začetak ideje o suradnji među knjižnicama i međuknjižničnoj posudbi smatra se 1876. godina kada je knjižničar Samuel S. Green prvi pozvao na takvu suradnju, no tek je 1917. uspostavljen nacionalni sustav za međuknjižničnu posudbu. ${ }^{17}$

Razvoj službe međuknjižnične posudbe bilježi se tek u 20. stoljeću kada se javljaju brojni centri za posudbu te se donose propisi i pravilnici za međuknjižničnu posudbu i objavljuju prvi radovi na temu. ${ }^{18} \mathrm{U}$ mjestu Boston Spa u Velikoj Britaniji 1962. godine osnovana je depozitarna knjižnica National Lending Li-

\footnotetext{
10 Miguel, T.M. Exchanging books in Western Europe: a brief history of international interlibrary loan. // International Journal of Legal Information 35, 3(2007), str. 499. DOI: https://doi. org/10.1017/S073112650000247X.

11 Miguel, T.M. Nav. dj., str. 501.

12 Kraus J.W. Prologue to library cooperation - ideals. // Library Trends 24(1975), Str. 169. [citirano: 2019-08-08]. Dostupno na: http://hdl.handle.net/2142/6847.

13 Histoire de la Bibliothèque nationale de France. [citirano: 2020-05-15]. Dostupno na: https:// www.bnf.fr/fr/histoire-de-la-bibliotheque-nationale-de-france.

14 Miguel, T.M. Nav. dj., str. 502.

15 Kraus J.W. Nav. dj., str. 169.

16 Miguel, T.M. Nav. dj., str. 507.

17 Chittick Stabler, K. A brief history of interlibrary loan with special reference to Indiana. // Indiana Libraries 2, 2(1982), Str. 42. [citirano: 2019-07-31]. Dostupno na: http://journals.iupui. edu/index.php/IndianaLibraries/article/view/17209.

18 Goldner, M.; K. Birch. Resource sharing in a cloud computing age. // Interlending \& Document Supply 40, 1(2012), Str. 4. DOI: https://doi.org/10.1108/02641611211214224.
} 
brary for Science and Technology (NLL) ${ }^{19}$ koja se 1973. godine spaja s National Central Library u British Library Lending Division (BLLD), danas British Library Document Supply Service (BLDSS), čija je zadaća posudba i dostava građe knjižnicama diljem svijeta uz naplatu usluge. ${ }^{20}$

U Hrvatskoj je još 1962. godine uspostavljena dobra suradnja među knjižnicama. Sustav je bio centraliziran. Središnja uloga dodijeljena je Nacionalnoj i sveučilišnoj knjižnici u Zagrebu koja je posredovala prilikom nabave građe izvan Hrvatske. Nakon 1970. godine dolazi do decentralizacije sustava. ${ }^{21}$ Istraživanje visokoškolskih i znanstvenih knjižnica provedeno 2015. godine ${ }^{22}$ pokazalo je da uslugu međuknjižnične posudbe pružaju gotovo sve hrvatske visokoškolske i znanstvene knjižnice, no usluga je nedovoljno automatizirana i nije sustavna.

\section{Tehnološke promjene}

U tradicionalnim knjižnicama međuknjižnična posudba ponajprije se oslanjala na tiskanu građu, tiskane knjižnične kataloge, slanje i vraćanje građe poštom. ${ }^{23}$ Prva značajnija tehnološka promjena koja je utjecala na međuknjižničnu posudbu i njezin značaj pojava je fotokopirnih strojeva šezdesetih godina 20. stoljeća. Uvođenje fotokopirnog stroja u knjižnice omogućuje slanje fotokopija određenog raspona stranica. To je osobito značajno za radove u časopisu gdje se umjesto posudbe cijelog broja šalju fotokopije traženog rada. ${ }^{24}$ Također u to vrijeme u knjižnice ulaze i telefaks-uređaji (faks) koji omogućavaju slanje dokumenta ili slike između dviju udaljenih knjižnica. ${ }^{25}$

Računala u knjižnice ulaze sedamdesetih godina 20. stoljeća zbog automatizacije poslovanja i povećanja učinkovitosti knjižničnih procesa (katalogizacije, posudbe, pretraživanja), a javljaju se i prvi strojno čitljivi katalozi. OCLC (Online

19 Tortzen, V. The National Lending Library for Science and Technology, Boston Spa, Yorkshire, England. // Libri 13, 2(2009), Str. 118. DOI: https://doi.org/10.1515/libr.1963.13.2.118.

20 Barr, K. The British library lending division: the first ten years. // Interlending \& Document Supply 11, 3(1983), Str. 79. DOI: https://doi.org/10.1108/eb008495.

21 Močnik, V. Interlending among the states of former Yugoslavia. // Interlending \& Document Supply 29, 3(2001), Str. 103-104. DOI: https://doi.org/10.1108/02641610110400275.

22 Morandini Ćavarović, I. Međuknjižnična posudba i srodne usluge dostave građe u hrvatskim visokoškolskim i znanstvenim knjižnicama: diplomski rad. Zagreb: Filozofski fakultet, 2015., str. 43. [citirano: 2019-08-13]. Dostupno na: http://darhiv.ffzg.unizg.hr/id/eprint/5770.

${ }^{23}$ O'Brien, K. The Contemporary Academic Library Resource Sharing Mission: Fragmentation or Evolution? // Journal of Interlibrary Loan, Document Delivery \& Electronic Reserve 26, 4-5(2017), str. 152. DOI: https://doi.org/10.1080/1072303X.2018.1465010.

${ }^{24}$ Kennedy, S. The role of commercial document delivery services in interlibrary loan. // Interlending \& Document Supply 15, 3(1987), str. 67. DOI: https://doi.org/10.1108/eb008542.

25 Schmidt, S. A reasonable facsimile. // The Bottom Line 8, 1(1995), str. 32. DOI: https://doi. org/10.1108/eb025436. 
Computer Library Center) 1971. godine uspostavlja mrežu knjižnica i započinje s kooperativnom katalogizacijom te 1979. uvodi i sustav za međuknjižničnu posudbu. ${ }^{26}$

Automatizacija poslovanja najprije se odražava na način slanja i primanja zahtjeva koji se umjesto poštom ili telefonom prosljeđuju putem elektroničke pošte. Pojavom interneta katalozi knjižnica postaju mrežno dostupni, a samim time i informacija o građi koju je sada lakše pronaći i uputiti zahtjev knjižnici koja ju posjeduje. Razvijaju se i prvi alati i servisi za međuknjižničnu posudbu. OCLC je još sedamdesetih uspostavio sustav koji je automatizirao slanje zahtjeva i ubrzao proces. ${ }^{27}$ Pojavljuju se programi za slanje dokumenata kao što su Ariel 1991. godine te Prospero i OCLC ILLiad. Ariel je omogućavao skeniranje i slanje te primanje radova u tiff - formatu, a dostava se vršila putem elektroničke pošte ili interneta. OCLC ILLiad 2003. godine uvodi u svoj program komponentu zvanu Odyssey: protokol koji je omogućavao automatsku konverziju poslanog rada u pdf-format, stavljanje rada na mrežno mjesto, o čemu bi korisnik dobio obavijest. Sve se vršilo automatski, bez potrebe za knjižničnim osobljem. ${ }^{28} \mathrm{U}$ Njemačkoj je 2000. godine stvoren konzorcij knjižnica iz Njemačke, Austrije i Švicarske. Taj konzorcij pokrenuo je sustav Subito za centralnu dostavu dokumenata koji postaje uspješan i izvan njemačkog govornog područja. ${ }^{29}$ Svi ti sustavi automatiziraju poslovanje i pospješuju učinkvitost službe međuknjižnične posudbe. Slijedom automatizacije javljaju se brojni, kako nacionalni, tako i globalni sustavi za međuknjižničnu posudbu (RapidILL, Relais, CLIO System, Kits, Academica, Tipasa, Worldshare).

Preko 10000 knjižnica uključeno je u WordShare sustav za međuknjižničnu posudbu. Skupni katalog knjižnica iz cijelog svijeta WorldCat čini osnovu sustava. WorldShare License Manager prikuplja i pohranjuje informacije o politikama izdavača i uvjetima licenciranja međuknjižnične posudbe. Za razmjenu dokumenata rabi se oblak gdje su dokumenti dostupni za određeni broj učitavanja ili su na raspolaganju do 30 dana. Interlibrary Fee management olakšava plaćanje, a naplata se vrši na osnovi mjesečnih obračuna. ${ }^{30}$ Brojne platforme za

26 Kennedy, S. Nav. dj., str. 68.

27 Egan, N. Opportunities for interlibrary loan and interlibrary loan librarians. // Journal of Interlibrary Loan, Document Delivery \& Electronic Reserve 17, 4(2007), Str. 44. DOI: https://doi. org/10.1300/J474v17n04_06.

${ }^{28}$ Connell, R. S.; K. L. Janke. Turnaround time between Illiad's Odyssey and Ariel delivery methods: a comparison // Journal of Interlibrary Loan, Document Delivery \& Electronic Reserve 16, 3(2006), str. 42. DOI: https://doi.org/10.1300/J474v16n03_07

29 Rosemann, U. Trends in German document delivery services (with particular reference to subito). // Interlending \& Document Supply 31, 3(2003), str. 181. DOI: https://doi. org/10.1108/02641610310488628.

30 Burke, G.; E. Duncan; J. Smither. Share resources through the largest interlibrary loan network. // Interlending \& Document Supply 44, 4(2016), Str. 137-138. [citirano: 2020-02-17]. Dostupno na https://doi.org/10.1108/ILDS-05-2016-0018. 
međuknjižničnu posudbu u sebi objedinjuju knjižnične kataloge i uslugu međuknjižnične posudbe (VPN The Virtual Polytechnic Library; CALIS - China Academic Library \& Information System; NEOS -Canadian cooperative library consortium), a također i većina integriranih knjižničnih sustava uključuje i modul međuknjižnične posudbe. U Hrvatskoj se 2003. pojavljuje program SEND (Sustav elektroničke nabave dokumenata) koji je u prvoj inačici bio namijenjen samo djelatnicima Instituta Ruđer Bošković. Druga verzija programa SEND, koja je započela s radom 2014. godine, omogućava uporabu programa svim hrvatskim knjižnicama. Osim programa SEND hrvatske knjižnice još rabe Kohu u kombinaciji s programom Request Tracker, filesender, program MKP 1.4, program SPSS, Lteko i dr. ${ }^{31}$

Među značajnijim promjenama novi su formati u kojima se publikacije pojavljuju. Osim tiskane građe u knjižnicama su sve više zastupljene elektroničke publikacije. Elektroničke publikacije olakšavaju međuknjižničnu posudbu, ali predstavljaju i izazov. Dolazi i do promjene terminologije pa se sve više rabe termini: opskrba dokumenata, dostava dokumenata, zajednička uporaba izvora. ${ }^{32}$

\subsection{Digitalna grada}

Elektroničke publikacije, odnosno digitalna građa postale su sastavni dio fonda knjižnica. Čine ih e-časopisi, e-knjige, e-disertacije, odnosno ocjenski radovi te zajedno predstavljaju e-izvore informacija. Često se isprepliću termini elektronički i digitalni pa e-izvore možemo opisati kao građu u digitalnom formatu koja je elektronički dostupna.

Iako se pojam digitalna i digitalizirana građa više vezuju uz mrežno dostupnu građu, knjižnice su započele s digitalizacijom građe mikrofilmiranjem periodičkih publikacija u svrhu arhiviranja novina i časopisa i zaštite rijetke i vrijedne građe. Mikrofilm se u komercijalne svrhe počinje rabiti 1920. godine, 1925. započinje mikrofilmiranje novina New York Times, a od 1938. mikrofilm u knjižnicama rabi se u svrhu zaštite građe. ${ }^{33}$ Mikrofilmiranje u svrhu zaštite rijetke i vrijedne građe nastavlja se pedesetih godina 20. stoljeća. Osim mikrofilma rabe se mikrokartica, mikrotisak, a nešto kasnije i mikrofiš. ${ }^{34}$

31 Morandini Ćavarović, I. Nav. dj., str. 32.

32 Golubović, V.; J. Lasić-Lazić. Međuknjižnična posudba: stanje i mogućnosti. // Vjesnik bibliotekara Hrvatske 54, 3(2011), Str. 109. [citirano: 2019-08-12]. Dostupno na: https://www.hkdrustvo.hr/vjesnik-bibliotekara-hrvatske/index.php/vbh/article/view/363/358.

${ }_{33}$ Canepi, K.; B. Ryder; M. Sitko; C. Weng. Managing microforms in the digital age. // American Library Association, 2013. [citirano: 2019-08-02]. Dostupno na: http://www.ala.org/alcts/resources/collect/serials/microforms.

34 Ellingson, M.W.; S. D. Morris. Interlibrary loan evolution to revolution. // Interlibrary Loan Practices Handbook / V. Boucher; edited by C. L. Weible, K. L. Janke. Chicago: American Library Association, 2011. Str. 8. 
Prvi elektronički časopisi pojavili su se još sedamdesetih godina dvadesetog stoljeća. ${ }^{35}$ CD-ROM se pojavljuje 1985. godine. ${ }^{36}$ U periodu od 1990. do 1993. javljaju se elektronički časopisi na CD-ROM-u ${ }^{37}$, no čini se da su bila točna predviđanja o prolaznosti te tehnologije. ${ }^{38}$

Publikacije u digitalnom obliku pojavile su se već sredinom 20 stoljeća. Međutim nije došlo do veće prihvaćenosti od strane korisnika sve do pojave globalne mreže (World Wide Web) 1989. godine, nakon čega dolazi do porasta mrežno dostupnih publikacija

Nakon eksperimentiranja s elektroničkim časopisima 1996. godina na neki način označava prekretnicu kada dolazi do velikog porasta mrežno dostupnih časopisa. ${ }^{39} \mathrm{U}$ to vrijeme svi značajniji izdavači osim tiskane inačice počinju objavljivati i elektroničku inačicu časopisa. Kad su u pitanju hrvatski mrežno dostupni znanstveni časopisi, do pojave portala Hrčak mali broj časopisa imao je svoju elektroničku inačicu. Hrčak je portal koji na jednom mjestu okuplja hrvatske časopise dostupne u otvorenom pristupu. Otkad je portal pokrenut 2005. godine, broj dostupnih časopisa neprekidno raste, a time raste i broj radova u otvorenom pristupu. ${ }^{40}$

Michael Hart 1971. godine započinje Projekt Gutenberg, a u Velikoj Britaniji 1976. godine osnovan je Oxford Text archive, čime započinje i povijest elektroničke knjige, odnosno knjige u digitalnom formatu. ${ }^{41}$ Kasnih osamdesetih i ranih devedesetih pojavljuju se e-knjige na CD-ROM-u. U knjižnice ulaze bibliografske baze podataka na CD-ROM-u, objavljuju se enciklopedije, rječnici, leksikoni i druga referentna građa. Rabe se za objavu različitih sadržaja: obrazovnih, zabavnih i stručnih. ${ }^{42}$. Nakon što je internet postao općeprihvaćen, brojni izdavači uključuju mrežno dostupne e-knjige u svoje kolekcije. Jedan od najvećih izdavača knjiga na CD-ROM-u, tvrtka Voyager, 1996. godine zbog loše distribucije, neadekvatnih programskih rješenja i privlačnosti interneta prestaje s izdavanjem knjiga

35 Tenopir, C. Towards electronic journals: realities for scientists, librarians, and publishers. Washington: Special libraries association, 2000.

36 Bevan, N. Transient technology? The future of CD-ROMs in libraries. // Program: electronic library and information systems 28, 1(1994), Str. 1. DOI: https://doi.org/10.1108/eb047155.

37 Tenopir, C.; D. W. King; P. Boyce; M. Grayson; Y. Zhang; M. Ebuen. Patterns of journal use by scientists through three evolutionary phases. // D-Lib Magazine 9, 5(2003). [citirano: 2019-0702]. Dostupno na: http://www.dlib.org/dlib/may03/king/05king.html.

38 Bevan, N. Nav. dj., str. 1.

39 Woodward, H.; F. Rowland; C. McKnight; C. Pritchett; J. Meadows. Café Jus: an electronic journals user survey. // Journal of Digital Information 1, 3(1998). [citirano: 2019-08-09]. Dostupno na: http://journals.tdl.org/jodi/article/view/12/11.

40 Konjević, S. Hrvatski znanstveni i znanstveno-Stručni časopisi u elektroničkome mrežnom okruženju. // Vjesnik bibliotekara Hrvatske 52, 1-4(2009), Str. 86. [citirano: 2019-08-12]. Dostupno na: https://www.hkdrustvo.hr/vjesnik-bibliotekara-hrvatske/index.php/vbh/article/view/460/455.

${ }^{41}$ Horvat, A.; D. Živković. Između javnosti i privatnosti: knjižnice u vremenu e-knjige. Zagreb: Hrvatska sveučilišna naklada, 2012. Str. 96.

42 Živković, D. Elektronička knjiga. Zagreb: Multigraf, 2001. Str. 177 
na CD-ROM-u. ${ }^{43} \mathrm{U}$ toj ranoj fazi uglavnom je riječ o inačici tiskane knjige. Prva platforma za e-knjigu NetLibrary pokrenuta je 1999. godine, Google Books pokrenut je 2004. godine kao Google Print Library Project. U to vrijeme i izdavači znanstvene literature započinju s izdavanjem e-knjiga ${ }^{44}$.

Korisnici su vrlo brzo prihvatili e-časopise, a kod knjiga prihvaćanje je išlo nešto sporije. Osim različitih formata i nedovoljne obaviještenosti o raspoloživosti e-knjige, korisnici su bili prisiljeni sjediti za računalom, a upravo je prenosivost bila značajna odlika tiskane knjige

Na tržištu se pojavljuje niz čitača elektroničkih knjiga, a danas je moguće e-knjige čitati i na pametnim telefonima. Zapravo se još 1996. godine pojavio Soft Book reader, no nije imao značajan utjecaj na prihvaćanje e-knjiga. OverDrive palm reader na tržište izlazi 2002. godine, Sony Reader 2005 godine, 2009. Nook Reader, a 2010. i iPad. Najveći uspjeh postiže e-čitač Kindle koji knjižara Amazon 2007. godine plasira na tržište, istovremeno nudeći e-knjige po povoljnoj cijeni. ${ }^{45}$. Lakša dostupnost, zaslon prilagođen čitanju, veći broj dostupnih naslova dovode do prihvaćanja e-knjiga.

U Hrvatskoj se devedesetih godina pojavljuju e-knjige na disketama i CDROM-u. Objavljuju se zvučne knjige, dječje knjige, turistički vodiči, priručnici, leksikoni i dr. Kad su u pitanju mrežne publikacije, do 2000. godine uglavnom je riječ o e-inačici tiskane knjige. Među prvim je izdavačima koji objavljuju mrežne e-knjige informatičke tematike Strijelac (2000. godine), koji objavljuje i prvi hrvatski roman (Zmajevo oko) na internetu. ${ }^{46}$ Društvo za promoviranje književnosti na novim medijima (DPKM) početkom 2001. pokrenulo je projekt i mrežnu stranicu „Besplatne elektroničke knjige“. CARNet i Bulaja naklada predstavili su projekt e-lektire 2009. godine. Platforme za e-knjigu Took book i Planet9 pojavile su se 2010. godine. ${ }^{47}$.

Osim knjiga i druge vrste građe započinju svoj digitalni život. Program digitalnih ocjenskih radova pokrenula je američka tvrtka UMI (danas ProQuest) devedesetih godina 20. stoljeća. Na konferenciji održanoj 2003. godine u Berlinu osnovan je The Networked Digital Library of Theses and Dissertations (NDLTD), čime je pokret postao međunarodni. Program Britanske knjižnice za međuknjiž-

43 Manley, L.; R. P. Holley. History of the ebook: the changing face of books. // Technical Services Quarterly 29, 4(2012), Str. 297. DOI: https://doi.org/10.1080/07317131.2012.705731.

44 Connaway, L. S.; H. Wicht. What happened to the e-book revolution? The gradual integration of e-books into academic libraries. // Journal of Electronic Publishing 10, 3(2007). DOI: http:// dx.doi.org/10.3998/3336451.0010.302.

45 Horvat, A.; D. Živković. Između javnosti i privatnosti: knjižnice u vremenu e-knjige. Zagreb Hrvatska sveučilišna naklada, 2012. Str 118-121.

46 Živković, D. Nav. dj., str. 174-192.

47 Velagić, Z.; F. Pehar. An overview of the digital publishing market in Croatia. // Libellarium 6, 1-2(2013), str. 56 [citirano: 2019-08-13]. Dostupno na: http://www.libellarium.org/index.php/ libellarium/article/view/184/198. 
ničnu posudbu ocjenskih radova (British Library's national thesis inter-library loan system) razvio se u digitalni sustav e-disertacija EthOS (e-thesis online) koji započinje s radom 2008. godine. Disertacije novijeg datuma već su bile izvorno digitalne, a za potrebe sustava provodila se digitalizacija tiskanih ocjenskih radova. ${ }^{48}$ Partnerstvo europskih istraživačkih organizacija oformljeno 2005. godine rezultiralo je stvaranjem europskog portala e-disertacija dostupnih u otvorenom pristupu DART-Europe: pan-European networking and services. ${ }^{49}$

Prvi institucijski repozitoriji u Hrvatskoj pojavljuju se 2007. godine. Kako su to bili fakultetski repozitoriji (Fakultet strojarstva i brodogradnje, Medicinski fakultet, Filozofski fakultet), uglavnom su se pohranjivali ocjenski radovi. ${ }^{50}$ Digitalni akademski repozitorij (DAR) pojavio se 2011. godine te 2013. godine postaje član DART- Europe. Repozitorij se više ne razvija, već se nalazi u okviru projekta DABAR (Digitalni akademski arhivi i repozitoriji). Nacionalni repozitorij završnih i diplomskih radova (ZIR) i Nacionalni repozitorij disertacija i znanstvenih magistarskih radova (DR) uspostavljeni su 2015. godine. ${ }^{51}$

Kao odgovor na politiku komercijalnih izdavača koji imaju monopol na tržištu te krize znanstvenog izdavaštva uslijed stalnog porasta cijene znanstvenih časopisa i otkazivanja pretplate od strane knjižnica, pojavljuje se inicijativa otvorenog pristupa. Iako je Paul Ginsparg još 1991. godine pokrenuo ArXiv (repozitorij slobodno dostupnih preprint radova iz područja fizike), početkom inicijative smatra se 2002. godina i donošenje Budimpeštanske inicijative za otvoreni pristup. Uz podršku brojnih zemalja inicijativa dobiva na značaju. Broj časopisa dostupnih u otvorenom pristupu raste tako da danas i komercijalni izdavači dopuštaju neke oblike otvorenog pristupa.

No osim putem repozitorija autori sve više svoje radove razmjenjuju putem društvenih mreža namijenjenih znanstvenicima. Među njima se ističu Research Gate i Academia. U novije vrijeme pojavljuju se i neki ilegalni portali poput Sci-Huba.

\subsection{Autorsko pravo, licencni ugovori}

Ulazak digitalne građe u knjižnice pozitivna je promjena koja olakšava uslugu međuknjižnične posudbe. Međuknjižnična posudba postaje učinkovitija. Radovi se šalju u digitalnom formatu, skraćuje se vrijeme dostave dokumenta ili bi sve to bilo moguće kad to ne bi onemogućavali licencni ugovori izdavača i autorsko pravo.

48 Joint, N. Online digital thesis collections and national information policy. // Library Review 58, 8(2009), str. 562. DOI: https://doi.org/10.1108/00242530910987055.

49 Moyle, M. DART-Europe: pan-European networking and services. // ALISS Quarterly 5, 2(2010), str. 37. [citirano: 2019-08-13]. Dostupno na: https://discovery.ucl.ac.uk/id/eprint/19059. 50 Krajna, T. Slobodan pristup informacijama: institucijski repozitoriji. // Polimeri 28(2007), 199-200. [citirano: 2019-08-12]. Dostupno na: https://hrcak.srce.hr/18974.

51 Holub, K.; L. Jertec. Interoperabilnost zapisa ocjenskih radova u Dabru. // Vjesnik bibliotekara Hrvatske 61, 1(2018), str. 494. DOI: https://doi.org/10.30754/vbh.61.1.632. 
Autorsko pravo pravo je autora na njihovim djelima iz književnoga, znanstvenog i umjetničkog područja. ${ }^{52}$ Cilj zakona zaštita je autora i njegova djela. Pravo autora može biti moralno i materijalno. S druge strane knjižnice su ustanove koje osiguravaju slobodan pristup informacijama. Kako bi se pomirile suprotnosti u zakonima o autorskom pravu, postoje iznimke kojima se knjižnicama dopušta uporaba i reproduciranje autorskog djela pod određenim uvjetima. ${ }^{53} \mathrm{U}$ anglosaksonskim zemljama rabi se termin copyright, a iznimke su definirane kao „fair use“ (poštena uporaba). Autori znanstvenih radova u časopisima zadržavaju moralna prava, a materijalna prava prenose na izdavače. U tiskanom okruženju to je dobro funkcioniralo: autori i njihova djela bili su zaštićeni, a knjižnice su osiguravale pristup informacijama.

Ulaskom digitalne građe na tržište zakon o autorskom pravu nije se odmah uskladio s novonastalom situacijom. Knjižnice su uglavnom radile prema zakonu koji se odnosi na tiskanu građu, a pravo i ograničenja pristupu uvjetuju izdavači putem licencnih ugovora. Upravo restrikcije koje donose novi zakoni ili licencni ugovori izdavača predstavljaju zapreke s kojima se suočava međuknjižnična posudba, a neke knjižnice i sustavi završili su na sudu.

U Njemačkoj su sustav Subito, Njemačka nacionalna knjižnica za znanost i tehnologiju (TIB Hannover), Njemačka nacionalna medicinska knjižnica (ZB MED) tužene zbog slanja građe elektroničkim putem. Za vrijeme suđenja Njemačka nacionalna medicinska knjižnica u potpunosti je obustavila međuknjižničnu posudbu. Knjižnice unutar sustava Subito dostavljale su putem elektroničke pošte skenirane radove iz tiskanih časopisa, ne izvorno digitalne radove. U to vrijeme (2004.) u Njemačkoj se raspravljalo o novom zakonu o autorskom pravu ${ }^{54}$ koji je bio prilično restriktivan kada je u pitanju dostava e-građe. Subito se odlučio za potpisivanje licencnih ugovora direktno s izdavačima i s Copyright Clearance Centerom (CCC). Za bilo koju vrstu dostave knjižnica naplaćuje autorske naknade. Kao kontrolu rabi sustav za upravljanje digitalnim pravima (Digital rights management - DRM). I dalje se šalju skenirani radovi iz tiskanih publikacija, premda se s izdavačima može dogovoriti i slanje izvorno digitalnih radova, no cijena je previsoka i često je jeftinije nabaviti rad putem plaćanja po pregledu (pay per view) na stranicama izdavača. ${ }^{55}$

\footnotetext{
52 Zakon o autorskom pravu i srodnim pravima: pročišćeni tekst zakona NN 167/03, 79/07, 80/11, 125/11, 141/13, 127/14, 62/17, 96/18 na snazi od 8.11.2018. // Zakon.hr [citirano:2020-07-29]. Dostupno na: https://www.zakon.hr/z/106/Zakon-o-autorskom-pravu-i-srodnim-pravima.

53 Horvat, A.; D. Živković. Knjižnice i autorsko pravo. Zagreb: Hrvatska sveučilišna naklada, 2009. Str. 31-41.

54 Stupio na snagu 1.1.2008.

55 Rosemann, U.; M. Brammer. Development of document delivery by libraries in Germany since 2003. // Interlending \& Document Supply 38, 1(2010), str. 28. DOI: https://doi. org/10.1108/02641611011025334.
} 
Izdavači u Kanadi tužili su knjižnicu Pravnog udruženja Odvjetničke komore, ${ }^{56}$ no ona je dobila parnicu temeljem poštene uporabe (fair use). ${ }^{57}$. Također je i švicarska knjižnica ETH Zürich u sporu s Elsevierom dobila parnicu gdje je odlukom suda utvrđeno da je dostava dokumenata elektroničkim putem legalna. ${ }^{58}$

Unatoč zaprekama knjižnice pronalaze načine kako bi putem međuknjižnične posudbe dostavljale građu elektronički. Kad su u pitanju znanstveni časopisi, to je već uobičajena praksa, a sve više knjižnica posuđuje i e-knjige. Istraživanja koje je provela RUSA STARS ${ }^{59}$ za 2015. i 2019. godinu pokazuju da većina knjižnica dostavlja građu elektronički, a licencni ugovori i dalje predstavljaju najveću zapreku međunarodnoj međuknjižničnoj posudbi. ${ }^{6061}$

\section{Međuknjižnična posudba u Centru za znanstvene informacije In- stituta Ruđer Bošković}

Od samog osnutka Knjižnica Instituta Ruđer Bošković62 (IRB) svojim korisnicima omogućava nabavu građe iz drugih knjižnica putem službe međuknjižnične posudbe. Prvi pisani trag potječe iz 1965. godine kada je međuknjižnična posudba spomenuta u godišnjem izvještaju Instituta. U cilju automatizacije procesa međuknjižnične posudbe izrađena je aplikacija SEND (Sustav elektroničke nabave dokumenata). Prva verzija zaživjela je 2003. godine i bila je namijenjena isključivo djelatnicima IRB-a, a hrvatskim knjižnicama omogućavala je slanje zahtjeva samo Knjižnici IRB-a za građu koju posjeduje. Poboljšana verzija SEND $2.0 \mathrm{~s}$ novim funkcionalnostima predstavljena je javnosti 2014. godine.

\footnotetext{
56 Great Library of the Law Society of Upper Canada

57 Tiessen, R. How copyright affects interlibrary loan and electronic resources in Canada. // Interlending \& DocumentSupply40, 1(2012), str.50.DOI:https://doi.org/10.1108/02641611211214297.

58 Tschirren, D.; A. Grossgarten. Cooperative Storage Library Switzerland (CSLS). // Beyond the paywall: resource sharing in disruptive ecosystem / ed. by P. D. Collins, S. Krueger \& S. Skenderija. Prag: National Library of Technology, 2019., str. 88. [citirano: 2020-02-13] Dostupno na: http://www.nusl.cz/ntk/nusl-407836.

59 Reference \& User Services Association's Sharing and Transforming Access to Resources Section, sekcija Američkog knjižničarskog društva koja se bavi pitanjima i mogućnostima zajedničke uporabe izvora, kao što su usluge poput međuknjižnične posudbe, dostave dokumenata, udaljene posudbe, udaljenog pristupa, koordiniranog razvoja zbirki i sl.

60 Munson, K.; H. H. Thompson; J. Cabaniss; H. Nance; P. Erlandsen. The world is your library, or the state of international interlibrary loan in 2015. // Interlending \& Document Supply 44, 2(2016), 44-57. DOI: https://doi.org/10.1108/ILDS-01-2016-0005.

61 Munson K.; H. H. Thompson. International interlibrary loan in a changing environment: results from the 2019 RUSA STARS international ILL survey. // Beyond the paywall: resource sharing in disruptive ecosystem / ed. by P. D. Collins, S. Krueger \& S. Skenderija. Prag: National Library of Technology, 2019. Str. 172-199. [citirano: 2019-12-13]. Dostupno na: http://www.nusl. cz/ntk/nusl-407836.

62 Od 2016. godine Centar za znanstvene informacije.
} 
U pogledu nabave građe uspostavljena je dobra suradnja s hrvatskim knjižnicama koja je osiguravala besplatnu nabavu građe na bazi reciprociteta. Na istom načelu, a na osnovi članstva ostvarena je suradnja s međunarodnim knjižničarskim društvima EURASLIC (European Association of Aquatic Sciences Libraries and Information Centres) i IAMSLIC (International Association of Aquatic and Marine Science Libraries and Information Centers). Od inozemnih knjižnica 1993. godine uspostavljena je suradnja s Britanskom knjižnicom, no danas joj se rijetko upućuju zahtjevi zbog visokih cijena nabave. Suradnja sa servisom Subito uspostavljena je 2004. godine. Građa se nabavljala i posredstvom slovenske Središnje tehničke knjižnice i njemačke nacionalne Knjižnice za znanost i tehnologiju (TIB Hannover). Ako građa nije bila dostupna u navedenim knjižnicama, zahtjevi su se upućivali i knjižnicama s kojima nije uspostavljena formalna suradnja ${ }^{63}$

Istraživanje provedeno na Institutu Ruđer Bošković ${ }^{64}$ pokazalo je kako je prema broju narudžbi međuknjižnična posudba na Institutu Ruđer Bošković vrlo intenzivna u razdoblju između 2003. i 2008. godine. Prosječni godišnji broj zahtjeva kretao se između 800 i 1000 zahtjeva upućenih od strane Knjižnice IRB-a drugim knjižnicama. U tom razdoblju ističe se 2005 . godina kad je zaprimljen i proslijeđen 1051 zahtjev. Broj zahtjeva drugih knjižnica upućenih Knjižnici IRB-a kretao se između 400 i 600 zahtjeva, s iznimkom 2007. godine kada je zaprimljeno 326 zahtjeva od drugih knjižnica.

Za navedeno istraživanje uporabljeni su podaci iz SEND-a 1.0 za razdoblje od 2003. do 2008. godine. Kao i kod drugih znanstvenih knjižnica, u zahtjevima prevladavaju oni za radovima iz časopisa $(93 \%$ ) te je stoga razumljivo da pojava e-časopisa ima značajnu ulogu u knjižničnim servisima, uključujući međuknjižničnu posudbu. Najviše se posuđivalo putem sustava Subito, knjižnice TIB Hannover, putem kataloga udruženja IAMSLIC te hrvatskih, većinom prirodnoznanstvenih knjižnica. U razdoblju nakon 2008. na prvom mjestu kao knjižnica od koje se najviše posuđuje knjižnice su udruženja EURASLIC/IAMSLIC. Subito i dalje igra značajnu ulogu zauzimajući drugo mjesto, nakon čega slijede hrvatske knjižnice.

Do 2008. godine većina zahtjeva bila je riješena uz naplatu (57,1\%), a 2008. godina prva je godina u kojoj je većina zahtjeva besplatno riješena. Danas se većina građe (95\%) nabavlja besplatno. Osim velikog broja pretplaćenih časopisa, kao i onih dostupnih u otvorenom pristupu, jedan je od razloga i povećana nabava građe putem IAMSLIC Z39.50 kataloga koji članovima udruženja omogućava besplatnu međuknjižničnu posudbu. IAMSLIC Z39.50 katalog predstavljen je na

63 Konjević, S.; B. Macan. SEND 2.0 - sustav elektroničke nabave dokumenata u novom ruhu // Vjesnik Bibliotekara Hrvatske 58, 1-2(2015), str. 163. [citirano: 2019-08-12]. Dostupno na: https://www.hkdrustvo.hr/vjesnik-bibliotekara-hrvatske/index.php/vbh/article/view/60/55.

${ }^{64}$ Macan, B.; S. Konjević. A survey of interlibrary loans at Ruder Bošković Institute Library, Croatia, 2003-2008. // Interlending and Document Supply 39, 1(2011), 45-52. DOI: https://doi. org/10.1108/02641611111112147. 
konferenciji EURASLIC, u Splitu 2005. godine. U početku je Knjižnica IRB-a bila skromna u svojim zahtjevima, no nakon nekog vremena počinje intenzivnije rabiti mogućnost besplatne međuknjižnične posudbe. Na slici 1. prikazan je broj zahtjeva Knjižnice IRB-a upućenih knjižnicama udruženja IAMSLIC putem IAMSLIC-kataloga za razdoblje od 2005. do 2018. godine. U razdoblju između 2009. i 2012. godine Knjižnica IRB-a prema statistici IAMSLIC Z39.50 kataloga bila je na prvom mjestu po broju poslanih zahtjeva. Nakon 2012. godine usluga nabave građe putem udruženja IAMSLIC ponovo se umjerenije rabi. ${ }^{65}$

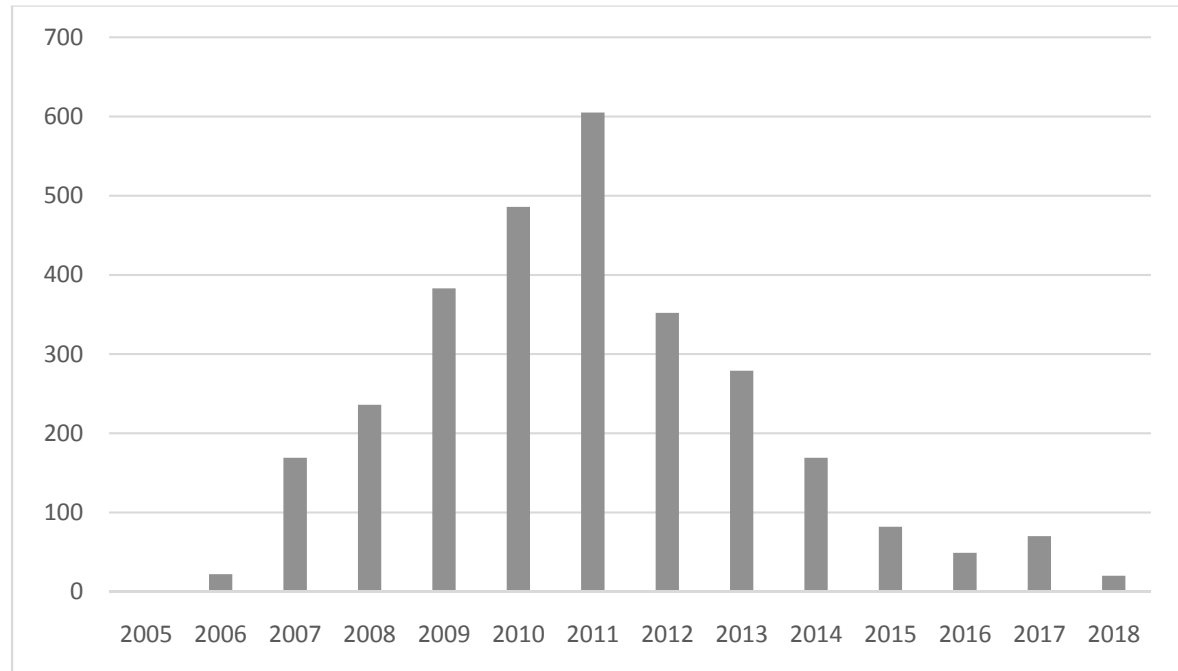

Slika 1. Broj zahtjeva Knjižnice IRB-a upućenih putem IAMSLIC-kataloga 2005. $-2018$.

Nije samo skromnost razlog umjerenije ili smanjene nabave putem IAMSLIC-kataloga već i smanjen broj zaprimljenih zahtjeva. Prosječni broj zahtjeva za međuknjižničnom posudbom u Knjižnici IRB-a isti je ili raste sve do 2013. godine. Po broju zaprimljenih zahtjeva ističu se 2011. i 2013. godina. Knjižnica IRB-a 2011. godine od drugih knjižnica zaprimila je 623 zahtjeva, a uputila je 1033 zahtjeva. Sličan broj zahtjeva, ukupno 1030, upućeno je drugim knjižnicama 2013. godine, a od drugih knjižnica zaprimljena su 374 zahtjeva, što je bio manji broj od broja zahtjeva zaprimljenih prethodnih godina. Iako nije rađena detaljna analiza, pretpostavka je da je do većeg broja zahtjeva došlo zbog specifičnog predmeta istraživanja, što je zahtijevalo nabavu radova iz časopisa koji nisu bili dostupni u Knjižnici IRB-a, na što upućuje povećan broj zahtjeva od strane po-

65 IAMSLIC Z39.50 DiStributed Library. Resource Sharing Statistics. [citirano: 2019-03-13] Dostupno na: https://www.iamslic.org/ill/stats.php. 
jedinih korisnika. Nakon 2014. godine dolazi do stalnog opadanja broja zahtjeva kako Knjižnice IRB-a prema drugim knjižnicama, tako i broja zahtjeva upućenih Knjižnici IRB-a (Sl.2).

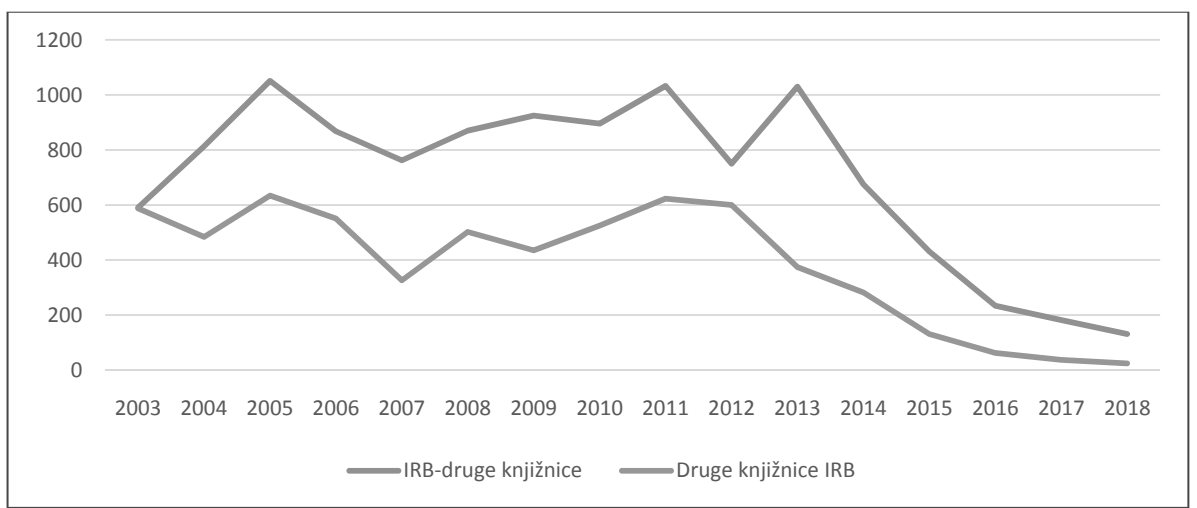

Slika 2. Broj zahtjeva Knjižnice IRB-a i drugih knjižnica prema Knjižnici IRB-a 2003. -2018 .

Na Institutu Ruđer Bošković godišnje se objavljuje preko 1000 radova, od čega oko 600 - 700 čine radovi objavljeni u znanstvenim časopisima. Tako je u promatranom razdoblju 2013. -2019. godine taj broj bio nešto niži za 2015. godinu kada je ukupno objavljeno 1210 radova, od čega 616 u časopisima. Najviši broj objavljenih radova bio je u 2017. godini, ukupno 1400 radova, od toga broja 736 bili su radovi objavljeni u časopisu. ${ }^{66}$. Kako znanstvena produktivnost nije bila smanjena, nije vidljiva korelacija između broja objavljenih radova i malog broja zaprimljenih zahtjeva. Slučajno se početna godina smanjivanja broja zahtjeva podudara s uvođenjem programa SEND 2.0., no ne dovodi se u vezu s trendom smanjenja broja zahtjeva. Za utvrđivanje stvarnih uzroka smanjivanja broja zahtjeva treba se provesti istraživanje među znanstvenicima kako bi se ustanovili načini nabave potrebne građe te na osnovi njihovih potreba istražili koliko je građe dostupno pretplatom ili u otvorenom pristupu. Iako nemamo empirijsku potvrdu, pretpostavljamo da je uzrok smanjenju broja zahtjeva velika dostupnost građe $u$ e-obliku bilo putem legalnih ili ilegalnih izvora, dostupnih zahvaljujući pretplati ili u otvorenom pristupu, što potvrđuju i slična iskustva nekih drugih knjižnica ili sustava poput British Librarya ili sustava Subito.

Subito bilježi pad broja zahtjeva nakon 2008. godine, i to čak do $50 \%$. Osim povećanog broja besplatno dostupnih radova izravan utjecaj na smanjenje među-

66 Navedeni podaci preuzeti su iz Hrvatske znanstvene bibliografije CROSBI u koji znanstvenici sami upisuju radove, tako da je stvarna produktivnost i veća jer vjerojatno nisu upisani baš svi objavljeni radovi 
knjižnične posudbe ima pretplata pristupa e-časopisima na nacionalnoj razini, koja uključuje i arhive časopisa.$^{67}$ Otvoreni pristup doveo je do povećanja broja dostupnih radova, čime izravno utječe na službu međuknjižnične posudbe. Schöpfel navodi da je prema nekim istraživanjima 30-50 \% znanstvenih radova dostupno u otvorenom pristupu. Osim otvorenog pristupa smanjenju zahtjeva doprinose i pretplate e-časopisa i e-knjiga velikih izdavača, digitalizacijski projekti. ${ }^{68}$ British Library Document Supply devedesetih godina bilježi porast zahtjeva, no nakon 2000. godine dolazi do smanjenja broja zahtjeva, a od 2011. godine dolazi do smanjenja broja međunarodnih zahtjeva. Razlog su ukidanje povlastica inozemnim knjižnicama zbog straha od mogućih tužbi vezanih uz kršenje autorskog prava. ${ }^{69}$. U Francuskoj je također zabilježen pad broja zahtjeva za međuknjižničnom posudbom (nakon 1997. godine broj zahtjeva smanjivao se za $8 \%$ godišnje) ${ }^{70}$, a neke zemlje poput Kine ne bilježe pad zahtjeva. ${ }^{71}$ Finska sveučilišta također bilježe pad u broju zahtjeva zahvaljujući publikacijama dostupnim u otvorenom pristupu, nelegalnim izvorima, a osobito zbog popularnosti društvene mreže ReserchGate ${ }^{72}$.

Sekcija američkog knjižničarskog društva RUSA STARS do sada je provela nekoliko globalnih istraživanja vezanih za politiku i praksu međuknjižnične posudbe. Istraživanje provedeno 2019. godine provedeno je u suradnji s IFLA-inom sekcijom za međuknjižničnu posudbu i dostavu dokumenata. Upitnik je dostavljen knjižnicima širom svijeta na sedam službenih jezika IFLA-e. Najveći broj odgovora pristigao je iz akademskih knjižnica. U odnosu na prethodna istraživanja zamijećeno je kako se sve više zahtjeva i građe dostavlja elektroničkim putem, a kao sredstvo plaćanja rabe se IFLA-voucheri. Kao prepreke međunarodnoj međuknjižničnoj posudbi istaknute su visoka poštarina, plaćanje, autorsko pravo, licence. Upravo su pregovori s izdavačima u pogledu uvjeta licenciranja međuknjižnične posudbe e-knjiga i druge e-građe nešto čemu se treba posvetiti u budućnosti kako bi se uklonile prepreke za međunarodnu međuknjižničnu posudbu. Istraživanje je pokazalo da neke knjižnice bilježe rast (35\%), druge bilježe pad broja zahtjeva (37\%), a ima i onih (28\%) kod kojih je taj broj ostao isti. Kao razlog

67 Rosemann, U.; M. Brammer. Nav. dj., str. 29.

68 Schöpfel, J. Open access and document supply. // Interlending \& Document Supply 42, 4(2014), str. 189. DOI: https://doi.org/10.1108/ILDS-10-2014-0049.

69 Appleyard, A. British Library Document Supply: an information service fit for the future. // Interlending \& Document Supply 43, 1(2015), str. 9. DOI: https://doi.org/10.1108/ILDS-11-20140055 .

70 Schöpfel, J.; J. Gillet. A review of interlending and document supply in France: 2010. // Interlending \& Document Supply 39, 2(2011), str. 78. DOI: https://doi.org/10.1108/02641611111138860.

71 Jia, P. The development of document supply services in China. // Interlending \& Document Supply 38, 3(2010), str. 156. DOI: https://doi.org/10.1108/02641611011072341.

72 Saarti, J.; K. Tuominen, From interlending to resource sharing between scholars: an analysis of recent developments. // Beyond the paywall: resource sharing in disruptive ecosystem / ed. by P. D. Collins, S. Krueger \& S. Skenderija. Prag: National Library of Technology, 2019. Str. 65. [citirano: 2019-12-13]. Dostupno na: http://www.nusl.cz/ntk/nusl-407836. 
porasta navode veću dostupnost informacije o građi, dok su kao razlog smanjenja navedene brojne alternativne mogućnosti nabave građe. ${ }^{73}$

Kao alternativni izvor 2011. godine pojavljuje se ilegalni izvor znanstvenih radova (Sci-Hub) koji nudi pristup znanstvenoj literaturi. Osobito su dobro pokriveni naslovi za koje je potrebna pretplata, nešto su manje zastupljeni radovi dostupni u otvorenom pristupu. Prosječna pokrivenost iznosi 77,8 \%, a kod pojedinih naslova pokrivenost je gotovo potpuna $(99,8 \%){ }^{74}$ Schöpfel smatra da su za uspjeh Sci-Huba zaslužni jednostavna uporaba, trenutni i besplatni pristup građi i dobra pokrivenost, a uzrok je njegove globalne uporabe disfunkcionalnost izdavačke industrije i nejednak pristup informacijama. ${ }^{75}$

\section{Zaključak}

Prethodno navedeni primjeri pokazali su da što je više građe dostupno korisnicima, bilo zahvaljujući pretplati, otvorenom pristupu ili nelegalnim izvorima, dolazi do smanjenja zahtjeva za međuknjižničnom posudbom. S obzirom na stalni porast broja dostupnih publikacija, postavlja se pitanje ima li međuknjižnična posudba budućnost.

Schöpfel smatra kako postoje radovi i istraživanja na temu i brojne konferencije posvećene međuknjižničnoj posudbi, sekcija IFLA-e, ali sve to nije dovoljno da privuče pozornost izvan uske ILDS-zajednice. ${ }^{76}$ Nelegalni izvori i otvorena znanost smanjuju značaj međuknjižnične posudbe. Sci-Hub nikako ne može biti zamjena dostavi dokumenata jer mu je pretraživanje rudimentarno, a osim toga ne poštuje se ni autorsko pravo. Da bi se dogodile pozitivne promjene, međuknjižnična posudba treba ponuditi bolje mogućnosti od postojećih. Pretraživanje i pronalaženje informacija trebalo bi biti učinkovitije, a uvjeti licenciranja inkorporirani u sustav. Usluga bi se trebala modernizirati, uklopiti u trendove otvorene znanosti i dostavljati na zahtjev korisnika znanstvene informacije o istraživanjima, sve radove bez obzira na vrstu publikacije, uključujući i znanstvene podatke. Prema Schöpfelu to bi trebao postati globalni servis, a ne lokalna knjižničnoorijentirana usluga. ${ }^{77}$

Časopis posvećen međuknjižničnoj posudbi Interlending \& Document Supply 2016. godine mijenja ime u Information Discovery and Delivery. Urednik časopi-

\footnotetext{
73 Munson K.; H. H. Thompson. Nav. dj., str. 172-199.

74 Himmelstein D. S.; A. R. Romero; J. G. Levernier; T. A. Munro; S. R. McLaughlin; B. Greshake Tzovaras;, C. S. Greene. Sci-Hub provides access to nearly all scholarly literature. // eLife (2018), 32822. [citirano: 2019-08-12] Dostupno na: https://elifesciences.org/articles/32822.

75 Schöpfel, J. Open supply? On the future of document supply in the world of open science. // Interlending \& Document Supply 44, 4(2016), str. 152. DOI: https://doi.org/10.1108/ILDS-072016-0025.

76 , Schöpfel, J. Open access. Nav. dj., str. 188.

77 Schöpfel, J. Open supply. Nav. dj., str. 152.
} 
sa Mike McGrath kaže da je do promjene naslova došlo zbog potrebe proširenja tematike časopisa s nečeg što je nekad bilo značajan dio knjižničnih aktivnosti, a to više nije. Smatra kako će međuknjižnična posudba ostati bitna knjižničarska usluga, a kao najveću zabludu današnjice vidi u uvjerenju kako je sve dostupno na internetu i to besplatno. ${ }^{78}$

Na međuknjižničnu posudbu možemo gledati kao na usku djelatnost nabave građe koju knjižnica ne posjeduje, ali također u širem kontekstu kao zajedničku uporabu izvora gdje se djelatnost proširuje na omogućavanje pristupa konzorcijskoj pretplati, pretplati pojedine knjižnice, osiguravanju pristupa građi u otvorenom pristupu, kao i pružanju usluge skeniranja na zahtjev. Prilikom dostave dokumenata u međuknjižničnoj posudbi uobičajeno je da se građa iz fonda knjižnice skenira i dostavlja elektronički drugim knjižnicama. Neke knjižnice nude tu uslugu i vlastitim korisnicima kao uslugu skeniranja na zahtjev. Ta usluga može biti dio međuknjižnične posudbe i već je zaživjela u nekim hrvatskim knjižnicama. ${ }^{79}$ British Library omogućuje izravnu dostavu dokumenata u dogovoru s izdavačima. Znanstveni se rad zahvaljujući ugovoru s izdavačima preprodaje korisniku uz naplatu autorske naknade..$^{80}$ IUPUI University Library (Indianapolis, SAD) putem jedinstvenog sučelja omogućuje pristup građi koja je dostupna u otvorenom pristupu zahvaljujući suradnji sa servisom Open Access Button, a za građu koja nije dostupna putem istog sučelja šalje se zahtjev za međuknjižničnom posudbom. ${ }^{81}$

Dostava e-građe putem usluge međuknjižnične posudbe ograničena je autorskim pravom, licencnim ugovorima, ali i činjenicom da knjižnice zapravo ne posjeduju e-građu, već imaju samo pravo pristupa, no unatoč navedenim razlozima sve više knjižnica dostavlja e-građu, uključujući i e-knjige. Tehnološka rješenja već postoje i mogu se unaprijediti, a nužni su daljnji pregovori s izdavačima kako bi se dogovorili uvjeti posudbe. Iako neka istraživanja pokazuju pad u broju zahtjeva, služba je još uvijek aktualna, što pokazuje i preko 10000 knjižnica iz 57 zemalja uključenih u najveću mrežu međuknjižnične posudbe WorldShare ILL. ${ }^{82}$

\footnotetext{
78 McGrath, M. A farewell from the editor to Interlending and Document Supply. // Interlending \& Document Supply 44, 4(2016), str. 186. DOI: https://doi.org/10.1108/ILDS-09-2016-0031.

79 Čnč, T. Razvoj e-usluge za udaljeno dohvaćanje knjižnične građe primjenom ITIL okvira: završni rad. Varaždin: Sveučilište u Zagrebu, Fakultet organizacije i informatike, 2013. Str. 11. [citirano: 2019-12-13]. Dostupno na: http://darhiv.ffzg.unizg.hr/id/eprint/4206.

80 Appleyard, A. UKRR - a collaborative collection management Strategy. // Beyond the paywall: resource sharing in disruptive ecosystem / ed. by P. D. Collins, S. Krueger \& S. Skenderija. Prag: National Library of Technology, 2019., str. 119. [citirano: 2020-02-13] Dostupno na: http:// www.nusl.cz/ntk/nusl-407836.

81 Paxton, M ; G. Maixner; J. McArthur; T. Baich. Engineering a powerfully simple interlibrary loan experience with InstantILL. // Beyond the paywall: Resource sharing in disruptive ecosystem / ed. by P. D. Collins, S. Krueger \& S. Skenderija. Prag: National Library of Technology, 2019. Str. 237. [citirano: 2020-02-13]. Dostupno na: http://www.nusl.cz/ntk/nusl-407836.

82 Burke, G.; E. Duncan; J. Smither. Nav. dj., str. 137-138.
} 
Međuknjižnična posudba može postojati kao zasebna usluga ili može biti integrirana u neki već postojeći knjižnični servis. Postoji sličnost između međuknjižnične posudbe i informacijske službe. Zadaća i jedne i druge traženje je literature, s tim što je MKP usmjerena globalno, a ne samo na građu koju posjeduje matična knjižnica. Svoje mjesto mogla bi naći i unutar posudbe, s posebnim naglaskom na uslugu skeniranja na zahtjev. ${ }^{83}$ Statistički podaci mogu se rabiti za kreiranje politike nabave građe, otkazivanja pretplate. Također svoje mjesto može naći u izgradnji zbirki traženjem alternativnih izvora znanstvenih informacija i besplatno dostupnih publikacija. ${ }^{84}$

Međuknjižnična posudba, kao i sve druge knjižnične usluge, izložena je stalnim promjenama kojima se mora prilagođavati. Uključivanje e-izvora nužno je za daljnji razvoj usluge kako bi se omogućila učinkovita i legalna dostava dokumenata, a služba modernizirala u skladu sa zahtjevima vremena. Možda će se u budućnosti transformirati u sasvim novu uslugu ili integrirati u neke druge knjižnične servise, no zasigurno će još neko vrijeme biti jedna od osnovnih knjižničnih djelatnosti.

\section{LITERATURA}

Appleyard, A. UKRR - a collaborative collection management strategy. // Beyond the paywall: resource sharing in disruptive ecosystem / ed. by P. D. Collins, S. Krueger \& S. Skenderija.Prag: National Library of Technology, 2019., str. 116-132. [citirano: 2020-02-13] Dostupno na: http://www.nusl.cz/ntk/nusl-407836.

Appleyard, A. British Library Document Supply: an information service fit for the future.

// Interlending \& Document Supply 43, 1(2015), 9-13. DOI: https://doi.org/10.1108/ ILDS-11-2014-0055.

Barr, K. The British library lending division: the first ten years. // Interlending \& Document Supply 11, 3(1983), 79-92. https://doi.org/10.1108/eb008495.

Bevan, N. Transient technology? The future of CD-ROMs in libraries. // Program: electronic library and information systems 28, 1(1994), 1-14. DOI: https://doi. org/10.1108/eb047155.

\footnotetext{
83 Percy, J. A game of loans: promoting interlibrary loans.] // The Machiavellian librarian: winning allies, combating budget cuts, and influencing stakeholders. / ed. by M. K. Aho, E. Bennett., Oxford [etc.]: Chandos Publishing, 2013. Str. 125-132. DOI: https://doi.org/10.1533/978178063 4364.2.125.

84 Posner, B. Library resource sharing in the early age of Google. // Library Philosophy and Practice 123(2007), 1-7. [citirano: 2020-05-13]. Dostupno na https://digitalcommons.unl.edu/ libphilprac/123.
} 
Burke, G.; E. Duncan; J. Smither. Share resources through the largest interlibrary loan network. // Interlending \& Document Supply 44, 4(2016), 137-140. [citirano: 202002-17]. Dostupno na https://doi.org/10.1108/ILDS-05-2016-0018.

Canepi, K.; B. Ryder; M. Sitko; C. Weng. Managing microforms in the digital age. // American Library Association, 2013. [citirano: 2019-08-02]. Dostupno na: http:// www.ala.org/alcts/resources/collect/serials/microforms.

Chittick Stabler, K. A brief history of interlibrary loan with special reference to Indiana. // Indiana Libraries 2, 2(1982), 42-53. [citirano: 2019-07-31]. Dostupno na: http:// journals.iupui.edu/index.php/IndianaLibraries/article/view/17209.

Connaway, L. S.; H. Wicht. What happened to the e-book revolution? The gradual integration of e-books into academic libraries. // Journal of Electronic Publishing 10, 3(2007). DOI: http://dx.doi.org/10.3998/3336451.0010.302.

Connell, R. S.; K. L. Janke. Turnaround time between Illiad's Odyssey and Ariel delivery methods: a comparison // Journal of Interlibrary Loan, Document Delivery \& Electronic Reserve 16, 3(2006), 41-56. DOI: https://doi.org/10.1300/J474v16n03_07.

Čonč, T. Razvoj e-usluge za udaljeno dohvaćanje knjižnične građe primjenom ITIL okvira: završni rad. Varaždin: Sveučilište u Zagrebu, Fakultet organizacije i informatike, 2013. [citirano: 2019-12-13]. Dostupno na: http://darhiv.ffzg.unizg.hr/id/ eprint/4206.

Echeverria, M.; P. Barredo. Online journals: their impact on document delivery. // Interlending \& Document Supply 33, 3(2005), 145-149. DOI: https://doi. org/10.1108/02641610510618036.

Egan, N. Opportunities for Interlibrary Loan and Interlibrary Loan Librarians. // Journal of Interlibrary Loan, Document Delivery \& Electronic Reserve 17, 4(2007), 43-54. DOI: https://doi.org/10.1300/J474v17n04_06.

Ellingson, M.W.; S. D. Morris. Interlibrary loan evolution to revolution. // Interlibrary Loan Practices Handbook / V. Boucher; edited by C. L. Weible, K. L. Janke. Chicago: American Library Association, 2011. Str. 1-16.

Goldner, M.; K. Birch. Resource sharing in a cloud computing age. // Interlending \& Document Supply 40, 1(2012), 4-11. DOI: https://doi.org/10.1108/02641611211214224.

Golubović, V.; J. Lasić-Lazić. Međuknjižnična posudba: stanje i mogućnosti. // Vjesnik bibliotekara Hrvatske 54, 3(2011), 107-126. [citirano: 2019-08-12]. Dostupno na: https://www.hkdrustvo.hr/vjesnik-bibliotekara-hrvatske/index.php/vbh/article/ view/363/358.

McGrath, M. A farewell from the editor to Interlending and Document Supply. // Interlending \& Document Supply 44, 4(2016), 186-190. DOI: https://doi.org/10.1108/ ILDS-09-2016-0031.

Miguel, T. M. Exchanging books in Western Europe: a brief history of international interlibrary loan. // International Journal of Legal Information 35, 3(2007), 498-513. DOI: https://doi.org/10.1017/S073112650000247X. 
Himmelstein D. S.; A. R. Romero; J. G. Levernier; T. A. Munro; S. R. McLaughlin; B. Greshake Tzovaras;, C. S. Greene. Sci-Hub provides access to nearly all scholarly literature. // eLife (2018), 32822. [citirano: 2019-08-12]. Dostupno na: https://elifesciences.org/articles/32822.

Holub, K.; L. Jertec. Interoperabilnost zapisa ocjenskih radova u Dabru. // Vjesnik bibliotekara Hrvatske 61, 1(2018), 489-508. DOI: https://doi.org/10.30754/vbh.61.1.632.

Horvat, A.; D. Živković. Između javnosti i privatnosti: knjižnice u vremenu e-knjige, Zagreb: Hrvatska sveučilišna naklada, 2012.

Horvat, A.; D. Živković. Knjižnice i autorsko pravo. Zagreb: Hrvatska sveučilišna naklada, 2009.

IAMSLIC Z39.50 Distributed Library. Resource sharing statistics. [citirano: 2019-0313]. Dostupno na: https://www.iamslic.org/ill/stats.php.

Jackson, M. E. Will electronic journals eliminate the need for ILL? // Interlending \& Document Supply 32, 3(2004), 192-193. DOI: https://doi.org/10.1108/02641610410699768.

Jia, P. The development of document supply services in China. // Interlending \& Document Supply 38, 3(2010), 152-157. DOI: https://doi.org/10.1108/02641611011072341

Joint, N. Online digital thesis collections and national information policy // Library Review, 58, 8 (2009), 561-568. DOI: https://doi.org/10.1108/00242530910987055.

Kennedy, S. The role of commercial document delivery services in interlibrary loan. // Interlending \& Document Supply 15, 3(1987), 67-73. DOI: https://doi.org/10.1108/ eb008542.

Konjević, S. Hrvatski znanstveni i znanstveno-stručni časopisi u elektroničkome mrežnom okruženju. // Vjesnik bibliotekara Hrvatske 52, 1-4(2009), 75-88. [citirano: 2019-08-12]. Dostupno na: https:/www.hkdrustvo.hr/vjesnik-bibliotekara-hrvatske/ index.php/vbh/article/view/460/455.

Konjević, S.; B. Macan. SEND 2.0 - sustav elektroničke nabave dokumenata u novom ruhu. // Vjesnik Bibliotekara Hrvatske 58, 1-2(2015), 161-174. [citirano: 2019-0812]. Dostupno na: https://www.hkdrustvo.hr/vjesnik-bibliotekara-hrvatske/index. $\mathrm{php} / \mathrm{vbh} /$ article/view/60/55.

Kraus J.W. Prologue to library cooperation - ideals. // Library Trends 24(1975), 169182. [citirano: 2019-08-08]. Dostupno na: http://hdl.handle.net/2142/6847.

Krajna, T. Slobodan pristup informacijama: institucijski repozitoriji. // Polimeri 28(2007), 199-200. [citirano: 2019-08-12]. Dostupno na: https://hrcak.srce.hr/18974.

Manley, L.; R. P. Holley. History of the ebook: the changing face of books. // Technical Services Quarterly 29, 4(2012), 292-311. DOI: https://doi.org/10.1080/07317131.2 012.705731 .

Macan, B.; S. Konjević. A survey of interlibrary loans at Ruder Bošković Institute Library, Croatia, 2003-2008. // Interlending and Document Supply 39, 1(2011), 45-52. DOI: https://doi.org/10.1108/02641611111112147. 
Močnik, V. Interlending among the states of formerYugoslavia.//Interlending \& Document Supply 29, 3(2001), 100-107. DOI: https://doi.org/10.1108/02641610110400275.

Morandini Ćavarović, I. Međuknjižnična posudba i srodne usluge dostave građe u hrvatskim visokoškolskim i znanstvenim knjižnicama: diplomski rad. Zagreb: Filozofski fakultet, 2015. [citirano: 2019-08-13]. Dostupno na: http://darhiv.ffzg.unizg. $\mathrm{hr} / \mathrm{id} /$ eprint $/ 5770$.

Moyle, M. DART-Europe: pan-European networking and services. // ALISS Quarterly 5, 2(2010), 37-40. [citirano: 2019-08-13]. Dostupno na: https://discovery.ucl.ac.uk/ $\mathrm{id} /$ eprint/19059.

Munson, K.; H. H. Thompson; J. Cabaniss; H. Nance; P. Erlandsen. The world is your library, or the state of international interlibrary loan in 2015. // Interlending \& Document Supply 44, 2(2016), 44-57. DOI: https://doi.org/10.1108/ILDS-01-2016-0005.

Munson K.; H. H. Thompson. International interlibrary loan in a changing environment: results from the 2019 RUSA STARS international ILL survey. // Beyond the paywall: resource sharing in disruptive ecosystem / ed. by P. D. Collins, S. Krueger \& S. Skenderija. Prag: National Library of Technology, 2019., str. 172-199. [citirano: 2019-12-13]. Dostupno na: http://www.nusl.cz/ntk/nusl-407836.

O'Brien, K. The contemporary academic library resource sharing mission: fragmentation or evolution? // Journal of Interlibrary Loan, Document Delivery \& Electronic Reserve 26, 4-5(2017), 151-155. DOI: https://doi.org/10.1080/107230 $3 \mathrm{X} .2018 .1465010$.

Paxton, M.; G. Maixner; J. McArthur; T. Baich. Engineering a powerfully simple interlibrary loan experience with InstantILL. // Beyond the paywall: resource sharing in disruptive ecosystem / ed. by P. D. Collins, S. Krueger \& S. Skenderija. Prag: National Library of Technology, 2019., str. 234-249. [citirano:2020-02-13]. Dostupno na: http://www.nusl.cz/ntk/nusl-407836.

Percy, J. A game of loans: promoting interlibrary loans.] // The Machiavellian librarian: winning allies, combating budget cuts, and influencing stakeholders / ed. by M. K. Aho, E. Bennett. Oxford [etc.]: Chandos Publishing, 2013., str. 125-132. DOI: https://doi.org/10.1533/9781780634364.2.125.

Posner, B. Library resource sharing in the early age of Google. // Library Philosophy and Practice 123(2007), 1-7. [citirano: 2020-05-13]. Dostupno na https://digitalcommons.unl.edu/libphilprac/123.

Rosemann, U. Trends in German document delivery services (with particular reference to Subito). // Interlending \& Document Supply 31, 3(2003), 180-183. DOI: https:// doi.org/10.1108/02641610310488628.

Rosemann, U.; M. Brammer. Development of document delivery by libraries in Germany since 2003. // Interlending \& Document Supply 38, 1(2010), 26-30. DOI: https://doi.org/10.1108/02641611011025334. 
Saarti, J.; K. Tuominen. From interlending to resource sharing between scholars: an analysis of recent developments. // Beyond the paywall: resource sharing in disruptive ecosystem / ed. by P. D. Collins, S. Krueger \& S. Skenderija.Prag: National Library of Technology, 2019., str. 57-68. [citirano: 2019-12-13]. Dostupno na: http:// www.nusl.cz/ntk/nusl-407836.

Schmidt, S. A reasonable facsimile. // The Bottom Line 8, 1(1995), 32-37. DOI: https:// doi.org/10.1108/eb025436.

Schöpfel, J. Open supply? On the future of document supply in the world of open science. // Interlending \& Document Supply 44, 4(2016), 150-154. DOI: https://doi. org/10.1108/ILDS-07-2016-0025.

Schöpfel, J. Open access and document supply. // Interlending \& Document Supply 42, 4(2014), 187-195. DOI: https://doi.org/10.1108/ILDS-10-2014-0049.

Schöpfel, J.; J. Gillet. A review of interlending and document supply in France: 2010. // Interlending \& Document Supply 39, 2(2011), 76-83. DOI: https://doi. org/10.1108/02641611111138860.

Tenopir, C. Towards electronic journals: realities for scientists, librarians, and publishers. Washington: Special libraries association, 2000.

Tenopir, C.; D. W. King; P. Boyce; M. Grayson; Y. Zhang; M. Ebuen. Patterns of journal use by scientists through three evolutionary phases. // D-Lib Magazine 9, 5(2003). [citirano: 2019-07-02]. Dostupno na: http://www.dlib.org/dlib/may03/king/05king. html.

Tiessen, R. How copyright affects interlibrary loan and electronic resources in Canada. // Interlending \& Document Supply 40, 1(2012), 49-54. DOI: https://doi. org/10.1108/02641611211214297.

Tschirren, D.; A. Grossgarten. Cooperative Storage Library Switzerland (CSLS). // Beyond the paywall: resource sharing in disruptive ecosystem / ed. by P. D. Collins, S. Krueger \& S. Skenderija.Prag: National Library of Technology, 2019. Str. 86-91. [citirano: 2019-12-13]. Dostupno na: http://www.nusl.cz/ntk/nusl-407836.

Tortzen, V. The National Lending Library for Science and Technology, Boston Spa, Yorkshire, England. // Libri 13, 2(2009), 118-126. DOI: https://doi.org/10.1515/ libr.1963.13.2.118.

Yue, P. W.; M. L. Syring. Usage of electronic journals and their effect on interlibrary loan: a case study at the University of Nevada, Reno. // Library Collections, Acquisitions, and Technical Services 28, 4(2004), 420-432. DOI: https://doi.org/10.1016/j. lcats.2004.08.002.

Velagić, Z.; F. Pehar. An overview of the digital publishing market in Croatia. // Libellarium 6, 1-2(2013), 55-64. [citirano: 2019-08-13]. Dostupno na: http://www.libellarium.org/index.php/libellarium/article/view/184/198.

Wiley, L.; T. E. Chrzastowski. The impact of electronic journals on interlibrary lending: a longitudinal study of statewide interlibrary loan article sharing in Illinois. // Li- 
brary Collections, Acquisitions, and Technical Services 29, 4(2005), 364-368. DOI: https://doi.org/10.1016/j.lcats.2006.03.015.

Woodward, H.; F. Rowland; C. McKnight; C. Pritchett; J. Meadows. Café Jus: an electronic journals user survey. // Journal of Digital Information 1, 3(1998). [citirano: 2019-08-09]. Dostupno na: http://journals.tdl.org/jodi/article/view/12/11.

Zakon o autorskom pravu i srodnim pravima: pročišćeni tekst zakona NN 167/03, 79/07, 80/11, 125/11, 141/13, 127/14, 62/17, 96/18 na snazi od 8.11.2018. // Zakon. hr [citirano:2020-07-29]. Dostupno na: https:/www.zakon.hr/z/106/Zakon-o-autorskom-pravu-i-srodnim-pravima.

Živković, D. Elektronička knjiga. Zagreb: Multigraf, 2001. 